\title{
Failure of Fibrous Composite Plates under Static Biaxial Planar Loading
}

\author{
Amir R. Khamseh* and Anthony M. Waas ${ }^{\dagger}$ \\ Department of Aerospace Engineering, University of Michigan, Ann Arbor, MI 48109-2118
}

\begin{abstract}
This paper outlines an experimental investigation carried out for the analysis of failure mechanisms in fibrous laminated composite plates containing stress raisers, in the form of cutouts, under static biaxial planar compressive loading. A specially designed biaxial loading frame was used to test a series of 48 ply graphite/epoxy composite laminated plates with centrally located circular holes under various compressive loading ratios.

Experimental results revealed failure initiation to occur in the $0^{0}$ plies at the edge of the hole, in the form of fiber kinking, for the Quasi-Isotropic and Generally Orthotropic specimens. Biaxial failure mechanisms exhibited a shift in the location of failure initiation at the hole edge as compared to the uniaxial cases. The Shear Dominated specimens exhibited large inplane wavelength microbuckles under uniaxial loading, and shear induced delaminations for the biaxial loadings.
\end{abstract}

\section{Introduction}

Recent advances in the manufacturing of fibrous composite materials, combined with their inherent high strength/stiffness to weight ratios, have given them a high priority in aerospace applications. However, due to the complex infrastructure of these materials, their behavior under various loading conditions has not been completely analyzed. Composite materials display a rather unique behavior under loading (and in subsequent failure) as compared to the traditional aerospace materials (i.e. metals such as steel and aluminum), which possess a very predictable and well understood stress-strain behavior. Although strong in tension, due

\footnotetext{
- Graduate Research Assistant, Student Member AIAA

tAsst. Professor of Aerospace Engineering, Senior Member AIAA. Copyright (C) 1994 by Anthony M. Waas. Published by the American Institute of Aeronautics and Astronautics, Inc. with permission.
}

to the fiber orientation in the plies, composite materials, made of brittle fibers and a polymeric matrix, under compressive loading exhibit a very quick and catastrophic progression of failure, rendering the material incapable of sustaining any subsequent loads. The brittle characteristic of the fibers and the interaction of the matrix has made the failure analysis of composites in compression complicated. In the aerospace field, plates made of these materials are to be used, where such structures will have regions of high stress concentration (in the form of holes, or cutouts) and will come under biaxial coplanar loading (i.e. fuselage panels). This paper outlines an experimental investigation carried out for the analysis of failure mechanisms in composite plates with centrally located circular holes under static biaxial planar compressive loading.

A recent experimental analysis of failure in specially designed uniply composite plates with varying hole sizes under static uniaxial compressive loading [1] was used as the foundation for this work. Experimental results reported therein revealed failure initiation to occur at the edge of the hole, in the form of fiber microbuckling/kinking followed by delamination, for specimens with hole sizes varying from the largest (corresponding to a hole diameter $d$ to plate width $w$ aspect ratio of $0.2)$ down to a cutoff hole size. Below this range, failure either initiated at the outer free edges, in the form of cracks, or was in the form of global (total) delamination. A Finite Element Analysis (FEA) incorporating classical lamination theory was carried out [2], utilizing the measured material properties and geometries, in order to gain insight into the inplane failure mechanisms evident in the experimental observations. The analysis modeled the graphite/epoxy uniply composite used in [1] in an attempt to reproduce the experimentally obtained results. The FEA results agreed very well with the buckled mode shapes from the experimental results, and although the estimated buckling loads were larger than those obtained from experiments, an area under current investigation by the authors, the trends 
for buckling modes and loads agree quite well for the two phases, revealing the inverse relation between failure load and hole diameter.

Initial biaxial test specimens consisted of a set of uniply graphite/epoxy specimens, with the same stacking geometry as for the uniaxial tests [1], with varying hole sizes, corresponding to hole diameter/plate width aspect ratios which resulted in failure initiation in the form of fiber microbuckling/kinking in the uniaxial tests, followed by a series of 48 ply graphite/epoxy composites (3 types: Quasi-Isotropic, Generally Orthotropic, and Shear Dominated) with two hole sizes, again for hole diameter/plate width aspect ratios corresponding to failure initiation at the hole edge. In all cases, the hole diameter to plate width aspect ratio remained in a range suitable for infinite plate assumptions (i.e. $w>5 d$ ). In this paper, only the results obtained for the $\mathbf{4 8}$ ply graphite/epoxy composites are presented.

\section{Previous Research}

Research into previous work [3-17] carried out for biaxial tests revealed a diverse array of applications and interpretations of dual axis loading. Whereas some work with biaxial testing dealt with axial/internal pressure loading of thin walled tubes $[3,4]$, others used a single axis loading at an angle to the fiber direction [5], or employed axial/transverse loading [6]. It was decided to focus our investigation on test work done with inplane biaxial loading of plates. Several important criteria were observed from these previous studies, namely that the optimal design of the test specimen would be a cruciform shape $[7,10,15,17]$, and for the test frame to employ four independently operated servohydraulic actuators [8], in order to avoid side bending loads on the specimen and have the center of the specimen remain stationary during the test. As pointed out in several of the papers $[16,17]$, problems are encountered with biaxial loading of specimens as far as achieving failure in the center of the specimen, due to fabrication and stress concentration problems involved with the cruciform design. Much of the inplane biaxial work carried out so far had dealt with a reduced central section or with cracks $[13,14]$ under fatigue loading [9].

The two works by Daniel $[11,12]$ addressed the failure behavior of composite plates under biaxial tensile loading, where the influence of hole diameter on failure was determined, first for equibiaxial ( $1:: 1)$ loading, and then for a 2::1 loading ratio. It was the purpose of the present investigation to utilize a mechanical approach in determining the nonlinear failure modes of composite plates under biaxial planar compressive loading. In order to keep the investigation as broad and general as possible, the simplified uniply graphite/epoxy composite plates used previously [1] were once again employed in the investigation of hole size on failure mode. The results from these tests were incorporated in the subsequent analysis and interpretation of results obtained from Quasi-Isotropic, Generally Orthotropic, and Shear Dominated graphite/epoxy plates. For the results reported herein dealing with the 48 ply composites, a variety of displacement loading ratios were used, (uniaxial, $1:: 1,2:: 1,1:: 2$ ), in order to capture a full failure envelope for these specimens. The unstable nature of failure in composites, as noted earlier, demanded a displacement controlled mode for the tests (as opposed to a load feedback mode) in order to allow for recovery of post failure data and examination of specimens loaded to initial (local) failure but recovered prior to global failure. This resulted in load ratios (inferred from the load cell data) which were not exactly precise integral values of the displacement ratios (for example, 1.8::1 loading ratio for a 2::1 displacement ratio), depending on the degree of orthotropy in the laminates.

\section{Test Specimens and Loading Apparatus}

The 48 ply test specimens were graphite/epoxy materials composed of Hercules IM7 fibers and NARMCO 5260 bismaleimide (brittle thermoset) matrix. Refer to Table 1 for the lamina properties, which were referenced from the work done by Gates at NASA [18]. The prepreg was manufactured at NARMCO and processed into panels at NASA LaRC. The glass transition temperature of these specimens, $\left(T_{g}\right)$, was approximately $220^{\circ} \mathrm{C}$. The stacking sequence for these symmetric laminates were as follows: Quasi-Isotropic $[+45 / 0 /-$ $45 / 90]_{6 s}$, Generally Orthotropic $\left[(+45 / 0 /-45 / 0)_{2} /+\right.$ $45 / 0 /-45 / 90]_{2 s}$, and Shear Dominated $[\mp 45 / \pm 45]_{6 s}$. Table 2 gives the laminate material properties (as determined from the analysis and verified in the tests) and stacking sequence for the three types of composite panels tested. Note the designations um1-, um2-, and um3- refer to the Quasi-Isotropic, Generally Orthotropic, and Shear Dominated composite types, respectively. The dimensions of the biaxial test plates are given in Fig. 1, where the thickness of the plates is approximately 0.285 inches (each with a 0.005 inch tolerance). A total of 30 NASA test specimens were examined for the two hole sizes, 9 each for the QuasiIsotropic and Shear Dominated specimens, and 12 for the Generally Orthotropic specimens.

Several studies were carried out for the design geometry of the specimen grips in order to assure for the constraints of the tests, namely alignment, rigidity, ac- 
cessibility, ease of use, ease of mounting, and repeatability given the working area in the frame and the geometric limitations of the specimens $(3.000 \times 1.250$ inch wide arms (see Fig. 1)). The final design that was implemented into the experimental work made use of four (one for each arm of the cruciform configuration of the specimens) stress proof steel grips with a $3.000 \times 1.500$ inch polished base which would come in contact with the load cell mounting plates or ball joints (see Fig. 2). In the center of the grip, a 0.290 inch channel 1.200 inches in depth was machined along the length of the grip. The specimen arm would sit in this channel, bonded to the walls of the channel with the use of DevCon plastic steel putty adhesive, treated with Dev-Con release agent in order to allow for simple separation of the two materials at the conclusion of the experiment. More importantly, the Dev-Con putty acted as an interface between the specimen edge and the grip surface on which the specimen 'sat', effectively smoothening out the interface surface irregularities between the two materials and ensuring a smooth load transfer. To ensure proper alignment of the specimen inside the channel (i.e. ensuring perfectly centered seating of the specimen inside the channel), metal shim plates of various thicknesses were added, as deemed necessary, to both sides of the specimen while inside the grip. As the grips were mated directly to the specimen and not to any portion of the test frame, the alignment of the test specimen inside the setup became crucial in avoiding bending effects under load.

Surface strain gage measurements at various locations on the specimen were recorded. Back to back strain gages were mounted along the edges of the hole, as well as in the corresponding far field region. In addition to these strain gages, a set of strain gages were mounted inside the hole, along the wall thickness, in order to record a quantitative change in strain in the material, revealing failure initiation under biaxial loading (see Fig. 3). Strain gage, along with load cell and piston LVDT, data were monitored via the computerized data acquisition system using an industry standard software package.

A biaxial loading apparatus was constructed from twin carbon-steel ( 16 pound weight carbon steel beams, with maximum carbon content of 0.25 ) I-beams which were welded and machined into an H-beam configuration, and incorporated servo hydraulic actuators that could be programmed in load or displacement feedback control. This biaxial load apparatus was used for all the tests reported herein. The operative dimensions of the frame are as follows: length of 72 inches, width of 36 inches, with a 20 inch square working "window" (see Fig. 2).

\section{Results and Discussion}

The graphite/epoxy NASA composites were tested with a displacement feedback control, where each opposing pair of pistons was programmed to move a certain distance in a specified time frame. Preliminary results indicated that a rate of 0.15 inches in $3000 \mathrm{sec}-$ onds for piston travel would assure for a static test. As mentioned, both pistons along each axis moved, maintaining symmetry about the midpoint of the plate. As the influence of hole size on the failure mode had been established and verified with the uniaxial [1] and biaxial tests of the unidirectional composites, only two hole sizes, namely 0.500 and 0.415 inch hole diameter, were used with the graphite/epoxy specimens, the focus being on developing a failure envelope for composite plates under various load ratios.

The Quasi-Isotropic specimens with the large (0.5 inch diameter) hole size gave similar failure initiation and global failure loads, as well as global failure modes, irrespective of the load paths (i.e. since the specimens have an equal number of $0^{\circ}, 90^{\circ}, \pm 45^{\circ}$ plies, the direction of loading will not be a factor in the failure $\mathrm{load} /$ mode of the specimen. This was verified from experimental results for various loading ratios as well as the laminate material properties shown in Table 2). In the cases of loading up through total specimen failure, there was evidence of ply (local) failure prior to the ultimate load carrying capacity of the specimen (indicated by the hole strain gages). Catastrophic failure in the specimen was marked by cracks initiating at the edges of the hole (perpendicular to the loading direction) and traversing towards the gripped arms. Two other tests were carried out with unloading prior to global, but after local, failure. These specimens were C-scanned and later deplied for damage detection. This approach was used for results from all three groups. The smaller (0.415) hole size specimens gave very similar local and global failure loads (refer to Table 3) and modes, with a slight increase in the global failure load values, as would be expected for a smaller stress raiser area.

The Generally Orthotropic specimens tested exhibited distinct failure initiation and final failure loads (and load ratios), although failure modes were similar to the Quasi-Isotropic cases. Here, the load carrying capacity of the specimen was much higher when the loading was along the direction which had more $0^{0}$. plies. Again, failure initiation was monitored by the drop in strain from the gages located inside the hole. The global failure loads did not increase much with the smaller hole size. An effort was made to capture local failure prior to global failure in some of the test specimens, but this proved to be quite difficult due to the 
almost instantaneous reaction time between local and global failure. Whereas the Quasi-Isotropic specimens revealed local failure initiation loads below the final load carrying capability of the structure, the Generally Orthotropic specimens had a much narrower 'window' between local and global failure loads.

The Shear Dominated specimens, similar to the Quasi-Isotropic specimens, are symmetric about the two loading axes, although in this case the symmetry stems from the fact that none of the plies have fibers running along (or perpendicular to) the loading axes (all plates have an equal number of plies at $\pm 45^{\circ}$ to the loading axes), and this was taken to our advantage to allow for several pairs of identical tests, with the second being stopped after local failure was observed, but prior to global failure, in order to investigate the localized failure phenomena. The final failure mode for the Shear Dominated specimens under biaxial loading was in the form of delamination cracks (i.e. cracks running at $45^{\circ}$ angles to the loading axes) traversing from the hole edge towards the notched free boundaries of the plate, running along the interface between plies, as will be made clear later by the results presented in Table 5. The uniaxial tests showed a localized failure phenomena in the form of long wavelength (on the order of 120 fiber diameter length) fiber microbuckles along the angle plies, at very high strains (again, refer to table 5). Failure loads for the smaller hole size do show a marked increase as compared to the large hole size, with the exception of the 1::1 displacement ratio.

\section{Failure Mechanisms}

In the composites containing $0^{0}$ plies (specifically the um1-and um2-series), failure initiated along the hole edge, in some cases traversing towards the gripped arms or open notches, and in other cases followed by failure at the grip/arm interface. Failure initiation for the QuasiIsotropic and Generally Orthotropic specimens started as fiber cracks at the edge of the hole, traversing towards the interior of the specimen as a band, not unlike uniaxially loaded specimens. However, the uniaxial tests resulted in the bands originating at the center of the hole edge, while biaxial tests showed a horizontal shift away from the hole center. Furthermore, both the uniaxial and biaxial tests showed the fibers within the bands having undergone a rotation by some angle and broken at the boundary of the band. For localized failure initiation, the Quasi-Isotropic and Generally Orthotropic specimens again (see [1]) revealed a 3D failure pattern (i.e. both inplane and out of plane fiber fracture modes), whereas the Shear Dominated specimens showed an inplane failure mode only. In one case where the specimen was uniaxially loaded, the initially circular hole was transformed into an elliptical shape with no apparent indication of local failure, revealing the very large deformations the specimen underwent without any drop in load. Upon deplying, large wavelength inplane buckle patterns were found, with no evidence of fiber breakage.

The ultirnate load carrying capability of the composites, for the hole diameters tested, is highest for the Generally Orthotropic specimens (when the loading was along the direction containing more $0^{\circ}$ plies), followed closely by the Quasi-Isotropic, with the Shear Dominated samples failing at approximately $66 \%$ of the Quasi-Isotropic loads. The far field stresses, corresponding to local failure initiation and final failure loads (as determined from the load cell data) divided by the cross sectional area of the specimen arms, are presented for the three types of specimens in Tables 3, 4 , and 5 , respectively, as a function of the hole size. Included in the tables are the failure initiation strains at the hole edge (obtained from strain gage readings which were corrected in order to take into account the finite width of the strain gages to record true hole strains), as well as the modes of failure which were identified during the sectioning and scanning studies. For each entry in these tables, the failure mechanism is described as either of four choices, designated as 0-ply 1, 0-ply 2, Angle ply 1 and Angle ply 2. These failure mechanisms are schematically represented in figure $5(\mathrm{a})-(\mathrm{d})$, with certain important characteristics, such as typical band width, microbuckling wavelength, etc., presented as normalized quantities, where the fiber diameter $d_{f}$ has been used as the characteristic length scale.

\section{Concluding Remarks}

A series of biaxial, inplane compressive loading tests were carried out on three types of graphite/epoxy composites in order to investigate the mechanisms involved in the compressive failure of these materials. It was determined that composite laminates containing plies oriented in the direction of the loading fail initially due to fiber kinking, leading to fiber breaks, whereupon this local instability leads to complete loss of load bearing capability for the system. In contrast, specimens having fibers oriented at an angle to a uniaxial loading direction exhibited long wavelength fiber microbuckling (at very high strains) and did not exhibit an immediate catastrophic failure mode, and the biaxial loading cases led to shear induced delamination cracks as the final failure mode. 


\section{Acknowledgements}

This study was partly funded by support received from NASA Langley Research Center Grant NAG-11040. Dr. M. J. Shuart was the program monitor at NASA LaRC. The authors are grateful for his support. References

1. Khamseh, A.R., and Waas, A.M., 1992, "Failure Mechanisms of Uniply Composite Plates with a Circular Hole Under Static Compressive Loading", ASME Trans. J. Eng. Materials and Tech., Vol. 114, July 1992, pp. 304-310.

2. Khamseh, A.R., and Waas, A.M., 1992, "Compression Failure Mechanisms of Uni-Ply Composite Plates with a Circular Cutout", AIAA 33rd Structures, Structural Dynamics \& Materials Conference, Dallas, TX, April 13-15.

3. Francis, P.H., Walrath, D.E., Sims, D.F., and Weed, D.N., 1977, "Biaxial Fatigue Loading of Notched Composites", Journal of Composite Materials, Vol. 11, pp. 488-501.

4. Swanson, S.R., and Christoforou, A.P., 1986, "Response of Quasi-Isotropic Carbon/Epoxy Laminates to Biaxial Stress", Journal of Composite Materials, Vol. 20, pp. 457-471.

5. Beuth, J.L., Jr., Gregory, M.A., and Herakovich, C.T., 1986, "Crack Growth in Unidirectional Graphite-Epoxy Under Biaxial Loading", Experimental Mechanics, September, pp. 245-253.

6. Kim, R.Y., and Crasto, A.S., 1992, "Prediction of Laminate Failure Under Combined Loading", Proceedings of the 8th Advanced Composites Conference, Chicago, Illinois, November 2-5, pp. 327-331.

7. Pascoe, K.J, and de Villiers, J.W.R., 1967, "Low Cycle Fatigue of Steels Under Biaxial Straining", Journal of Strain Analysis, Vol. 2, No. 2, pp. 117126.

8. Parsons, M.W., and Pascoe, K.J., 1975, "Development of a Biaxial Fatigue Testing Rig", Journal of Strain Analysis, Vol. 10, No. 1, pp. 1-9.

9. Hopper, C.D., and Miller,K.J., 1977, "Fatigue Crack Propagations in Biaxial Stress Fields", Journal of Strain Analysis, Vol. 12, No. 1, pp 23-28.

10. Charvat, I.M.H., and Garrett, G.G., 1980, "The Development of a Closed-Loop, Servo-Hydraulic Test System for Direct Stress Monotonic and
Cyclic Crack Propagation Studies Under Biaxial Loading", Journal of Testing and Evaluation, Vol. 8, No. 1, pp. 9-17.

11. Daniel, I.M., 1980, "Behavior of Graphite/Epoxy Plates with Holes under Biaxial Loading", Experimental Mechanics, January, pp. 1-8.

12. Daniel, I.M., 1982, "Biaxial Testing of $\left[0_{2} / \pm 45\right]$. Graphite/Epoxy Plates with Holes", Experimental Mechanics, May, pp. 188-195.

13. Jones, D. L., Poulose, P.K. and Liebowitz, H., 1986, "The Effects of Biaxial Loading on the Fracture Characteristics of Several Engineering Materials", Engineering Fracture Mechanics, Vol. 24, No. 2, pp. 187-205.

14. Hawong, J.S., Kobayashi, Dadkhah, M.S., Kang, B.S.-J., and Ramulu, M., 1987, "Dynamic Crack Curving and Branching Under Biaxial Loading", Experimental Mechanics, June, pp. 146-153.

15. Ferron, G., and Makinde, A., 1988, "Design and Development of a Biaxial Strength Testing Device", Journal of Testing and Evaluation, Vol. 16, No. 3, pp. 253-256.

16. Makinde, A., Thibodeau, L. and Neale, K.W., 1992, "Development of an Apparatus for Biaxial testing Using Cruciform Specimens", Experimental Mechanics, June, pp. 138-144.

17. Makinde, A. Neale, K.W., and Sacharuk, Z., 1992, "A Strain-Based Parametric Biaxial Failure Criterion For Fiber- Reinforced Composites", Polymer Composites, Vol. 13, No. 4, pp.263-272.

18. Gates, Thomas S., 1991, "Experimental Characterization of Nonlinear, Rate Dependant Behavior in Advanced Polymer Matrix Composites", Proceedings of the 1991 SEM Spring Conference, Milwaukee, WI, June 10-13. 


\begin{tabular}{||c|c|c|c|c|c||}
\hline \hline Material & $\begin{array}{c}E_{x} \\
(\mathrm{Msi})\end{array}$ & $\begin{array}{c}E_{y} \\
(\mathrm{Msi})\end{array}$ & $\begin{array}{c}G_{x y} \\
(\mathrm{Msi})\end{array}$ & $\nu_{x y}$ & $\begin{array}{c}\text { Thickness } \\
(\text { inch })\end{array}$ \\
\hline \hline $\mathrm{IM} 7 / 5260$ & 22.2 & 1.26 & 0.754 & 0.30 & $5.94 \times 10^{-3}$ \\
\hline \hline
\end{tabular}

Table 1: Lamina $0^{0}$-ply material properties

\begin{tabular}{||c|c|c|c|c|c||}
\hline \hline $\begin{array}{c}\text { Laminate } \\
\text { Type }\end{array}$ & $\begin{array}{c}\text { Stacking } \\
\text { Sequence }\end{array}$ & $\begin{array}{c}E_{x} \\
(\mathrm{Msi})\end{array}$ & $\begin{array}{c}E_{y} \\
(\mathrm{Msi})\end{array}$ & $\begin{array}{c}G_{x y} \\
(\mathrm{Msi})\end{array}$ & $\nu_{x y}$ \\
\hline \hline Quasi-Isotropic (um1-) & {$[+45 / 0 /-45 / 90]_{6 s}$} & 8.43 & 8.43 & 3.23 & 0.307 \\
Generally Orthotropic (um2-) & {$\left[(+45 / 0 /-45 / 0)_{2} /+45 / 0 /-45 / 90\right]_{2 s}$} & 5.17 & 11.4 & 3.23 & 0.223 \\
Shear Dominated (um3-) & {$[\mp 45 / \pm 45]_{6 s}$} & 2.68 & 2.68 & 5.70 & 0.779 \\
\hline \hline
\end{tabular}

Table 2: Laminate material properties

\begin{tabular}{|c|c|c|c|c|c|c|c|c|c|}
\hline Specimen & $\begin{array}{l}\text { Hole } \\
\text { Dia. } \\
\text { (in.) }\end{array}$ & $\alpha, \beta^{1}$ & $\begin{array}{l}\text { Failure } \\
\text { Mode }^{2}\end{array}$ & $\begin{array}{c}\text { Far Field } \\
\text { Final } \\
\text { Failure } \\
\text { Stress } \sigma_{\mathrm{y}} \\
\text { (ksi) }\end{array}$ & $\begin{array}{c}\text { Far Field } \\
\text { Final } \\
\text { Failure } \\
\text { Stress } \sigma_{\mathrm{x}} \\
\text { (ksi) }\end{array}$ & $\begin{array}{c}\text { Far Field } \\
\text { Initial } \\
\text { Failure } \\
\text { Stress } \sigma_{\mathbf{x}} \\
\text { (ksi) }\end{array}$ & $\begin{array}{c}\text { Far Field } \\
\text { Initial } \\
\text { Failure } \\
\text { Stress } \sigma_{y} \\
\text { (ksi) }\end{array}$ & $\begin{array}{c}\text { Gage } 9 \\
\text { Strain at } \\
\text { Failure } \\
\text { Initiation } \\
\text { ( } \mu \text { strain) }\end{array}$ & $\begin{array}{c}\text { Gage } 11 \\
\text { Strain at } \\
\text { Failure } \\
\text { Initiation } \\
\text { ( } \mu \text { strain) }\end{array}$ \\
\hline um1-1 & 0.4 & 1,1 & 0 -ply 2 & 37.5 & 40.1 & 21.1 & 21.5 & 4400 & 3800 \\
\hline uml-2 & 0.4 & 1,0 & $\mathrm{NA}^{3}$ & 0.0 & 38.9 & NA & NA & NA & NA \\
\hline um1-4 & 0.4 & 2,1 & 0 -ply 2 & 25.6 & 49.4 & 16.6 & 30.2 & 8200 & 1500 \\
\hline um1-5 & 0.5 & 1,1 & 0 -ply 2 & 39.3 & 39.6 & 29.2 & 29.7 & 10300 & 5500 \\
\hline um1-6 & 0.5 & 1,0 & 0 -ply 1 & 0.0 & 38.3 & 0.0 & 35.1 & 15000 & 4300 \\
\hline um1-9 & 0.5 & 1,2 & 0 -ply 2 & 52.6 & 27.9 & 31.9 & 18.1 & 2500 & 11000 \\
\hline um1-10 & 0.5 & 2,1 & 0 -ply 2 & 26.0 & 48.0 & 17.2 & 32.3 & 10800 & 8000 \\
\hline um1-11 & 0.5 & 0,1 & NA & $\mathrm{TS}^{4}$ & TS & 0.0 & 31.6 & 1500 & 16400 \\
\hline um1-12 & 0.5 & 1,2 & 0 -ply 2 & TS & TS & 35.0 & 20.2 & 2000 & 12700 \\
\hline
\end{tabular}

${ }_{2}^{1}$ Displacement Ratios. Refer to Figure 4.

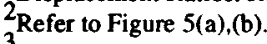

3 No data available.

${ }^{4}$ Test Stopped.

Table 3: Test Results for Quasi-Isotropic Specimens 


\begin{tabular}{|c|c|c|c|c|c|c|c|c|c|}
\hline Specimen & $\begin{array}{l}\text { Hole } \\
\text { Dia. } \\
\text { (in.) }\end{array}$ & $\alpha, \beta^{1}$ & $\begin{array}{l}\text { Failure } \\
\text { Mode }^{2}\end{array}$ & $\begin{array}{c}\text { Far Field } \\
\text { Final } \\
\text { Failure } \\
\text { Stress } \sigma_{\mathbf{y}} \\
(\mathrm{ksi})\end{array}$ & $\begin{array}{c}\text { Far Field } \\
\text { Final } \\
\text { Failure } \\
\text { Stress } \sigma_{\mathbf{x}} \\
(\mathbf{k s i})\end{array}$ & $\begin{array}{c}\text { Far Field } \\
\text { Initial } \\
\text { Failure } \\
\text { Stress } \sigma_{x} \\
(\mathrm{ksi})\end{array}$ & $\begin{array}{c}\text { Far Field } \\
\text { Initial } \\
\text { Failure } \\
\text { Stress } \sigma_{\mathrm{y}} \\
(\mathrm{ksi})\end{array}$ & $\begin{array}{c}\text { Gage } 9 \\
\text { Strain at } \\
\text { Failure } \\
\text { Initiation } \\
(\mu \text { strain) }\end{array}$ & $\begin{array}{c}\text { Gage 11 } \\
\text { Strain at } \\
\text { Failure } \\
\text { Initiation } \\
\text { ( } \mu \text { strain) }\end{array}$ \\
\hline um2-1 & 0.4 & 1,1 & 0 -ply 2 & 35.8 & 41.3 & 34.3 & 39.9 & 9000 & 5000 \\
\hline um2-2 & 0.4 & 0,1 & $\mathrm{NA}^{3}$ & 0.0 & 46.5 & NA & NA & NA & NA \\
\hline um2-3 & 0.4 & 1,0 & NA & 25.3 & 0.0 & NA & NA & NA & NA \\
\hline um2-7 & 0.4 & 1,2 & NA & 25.4 & 49.6 & NA & NA & NA & NA \\
\hline um2-8 & 0.4 & 2,1 & NA & 43.3 & 24.0 & NA & NA & NA & NA \\
\hline $\mathrm{um} 2-4$ & 0.5 & 1,0 & 0 -ply 1 & $\mathrm{TS}^{4}$ & TS & 22.6 & 0.0 & 2800 & 14500 \\
\hline um2-5 & 0.5 & 1,0 & 0-ply 1 & 27.8 & 0.0 & 22.2 & 0.0 & NA & NA \\
\hline um2-6 & 0.5 & 1,1 & NA & 40.6 & 41.2 & NA & NA & NA & NA \\
\hline um2-9 & 0.5 & 2,1 & NA & 47.1 & 28.9 & NA & NA & NA & NA \\
\hline um2-10 & 0.5 & 1,2 & 0 -ply 2 & 26.0 & 51.4 & 25.7 & 50.9 & 15900 & 3800 \\
\hline um2-11 & 0.5 & 0,1 & NA & 0.0 & 48.7 & NA & NA & NA & NA \\
\hline um2-12 & 0.5 & 1,2 & NA & 23.6 & 49.0 & NA & NA & NA & NA \\
\hline
\end{tabular}

${ }_{1}^{1}$ Displacement Ratios. Refer to Figure 4.

2 Refer to Figure 5(a),(b).

${ }^{3}$ No data available.

4 Test Stopped.

Table 4: Test Results for Generally Orthotropic Specimens

\begin{tabular}{|c|c|c|c|c|c|c|c|c|c|}
\hline Specimen & $\begin{array}{l}\text { Hole } \\
\text { Dia. } \\
\text { (in.) }\end{array}$ & $\alpha, \beta^{1}$ & $\begin{array}{l}\text { Failure } \\
\text { Mode }^{2}\end{array}$ & $\begin{array}{c}\text { Far Field } \\
\text { Final } \\
\text { Failure } \\
\text { Stress } \sigma_{y} \\
\text { (ksi) }\end{array}$ & $\begin{array}{c}\text { Far Field } \\
\text { Final } \\
\text { Failure } \\
\text { Stress } \sigma_{\mathrm{x}} \\
\text { (ksi) }\end{array}$ & $\begin{array}{c}\text { Far Field } \\
\text { Initial } \\
\text { Failure } \\
\text { Stress } \sigma_{\mathrm{x}} \\
\text { (ksi) }\end{array}$ & $\begin{array}{c}\text { Far Field } \\
\text { Initial } \\
\text { Failure } \\
\text { Stress } \sigma_{y} \\
\text { (ksi) }\end{array}$ & $\begin{array}{c}\text { Gage } 9 \\
\text { Strain at } \\
\text { Failure } \\
\text { Initiation } \\
\text { ( } \mu \text { strain) }\end{array}$ & $\begin{array}{c}\text { Gage } 11 \\
\text { Strain at } \\
\text { Failure } \\
\text { Initiation } \\
\text { ( } \mu \text { strain) }\end{array}$ \\
\hline um3-1 & 0.4 & 1,1 & $\mathrm{NA}^{3}$ & 26.7 & 26.7 & NA & NA & NA & NA \\
\hline um3-2 & 0.4 & 1,0 & NA & 31.3 & 0.0 & NA & NA & NA & NA \\
\hline um3-7 & 0.4 & 1,2 & Angle ply 2 & 23.0 & 36.3 & 10.1 & 19.2 & 9000 & 3000 \\
\hline um3-8 & 0.4 & 0,1 & Angle ply 1 & $\mathrm{TS}^{4}$ & TS & 0.0 & 23.4 & 18500 & 30000 \\
\hline um3-3 & 0.5 & 1,0 & Angle ply 1 & 23.8 & 0.0 & 22.2 & 0.0 & 23500 & 17000 \\
\hline um3-9 & 0.5 & 2,1 & Angle ply 2 & TS & TS & 33.2 & 22.4 & 15500 & 1100 \\
\hline um3-10 & 0.5 & 1,2 & Angle ply 2 & 21.3 & 32.2 & 18.4 & 29.0 & 1500 & 12500 \\
\hline um3-11 & 0.5 & 1,0 & Angle ply 1 & TS & TS & 0.0 & 23.3 & 31400 & 16200 \\
\hline um3-12 & 0.5 & 1,1 & NA & 35.1 & 37.4 & NA & NA & NA & NA \\
\hline
\end{tabular}

${ }_{1}^{1}$ Displacement Ratios. Refer to Figure 4.

${ }_{3}^{2}$ Refer to Figure 5(c),(d).

3 No data available.

${ }^{4}$ Test Stopped.

Table 5: Test Results for Shear Dominated Specimens 


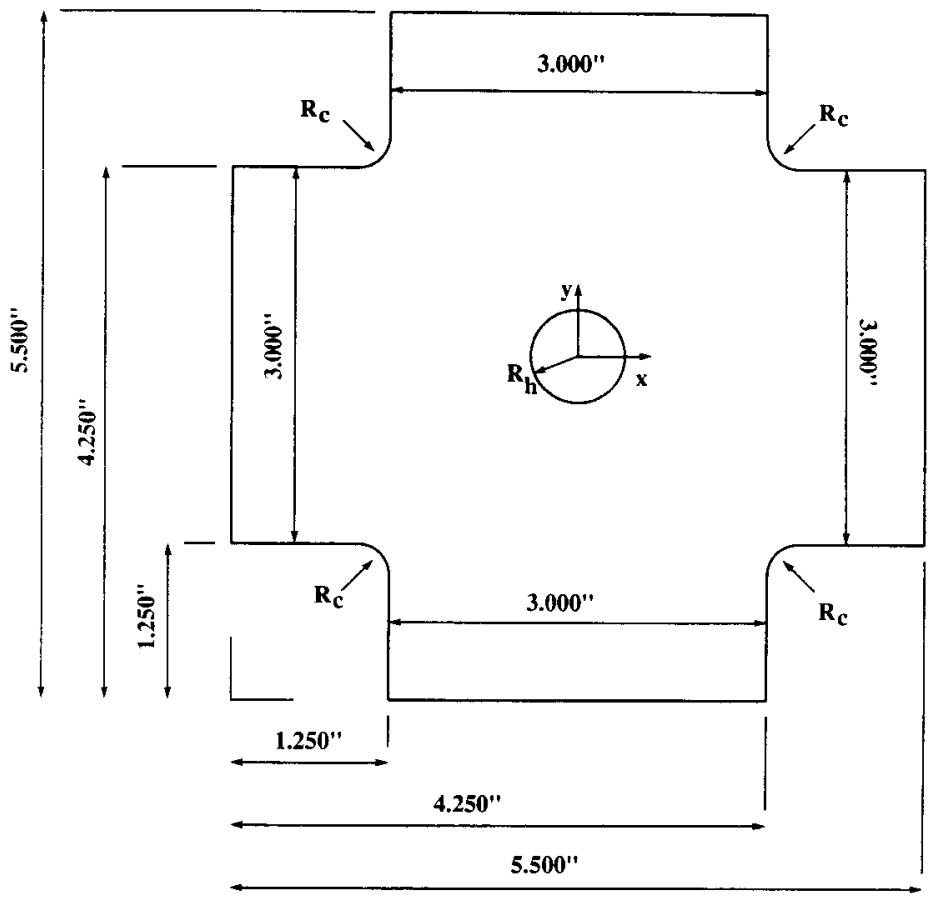

All dimensions are given in inches $(+/-0.005$ inch tolerance)

NOTE: Specimen is SYMMETRIC about the $\mathrm{x}$ and $\mathrm{y}$ axes

radius of curvature $R_{c}=0.250$ "

Hole radii $R_{h}=\left(0.2075^{\prime \prime}, 0.2500^{\prime \prime}\right)$

Fig. 1 Biaxial Specimen Geometry

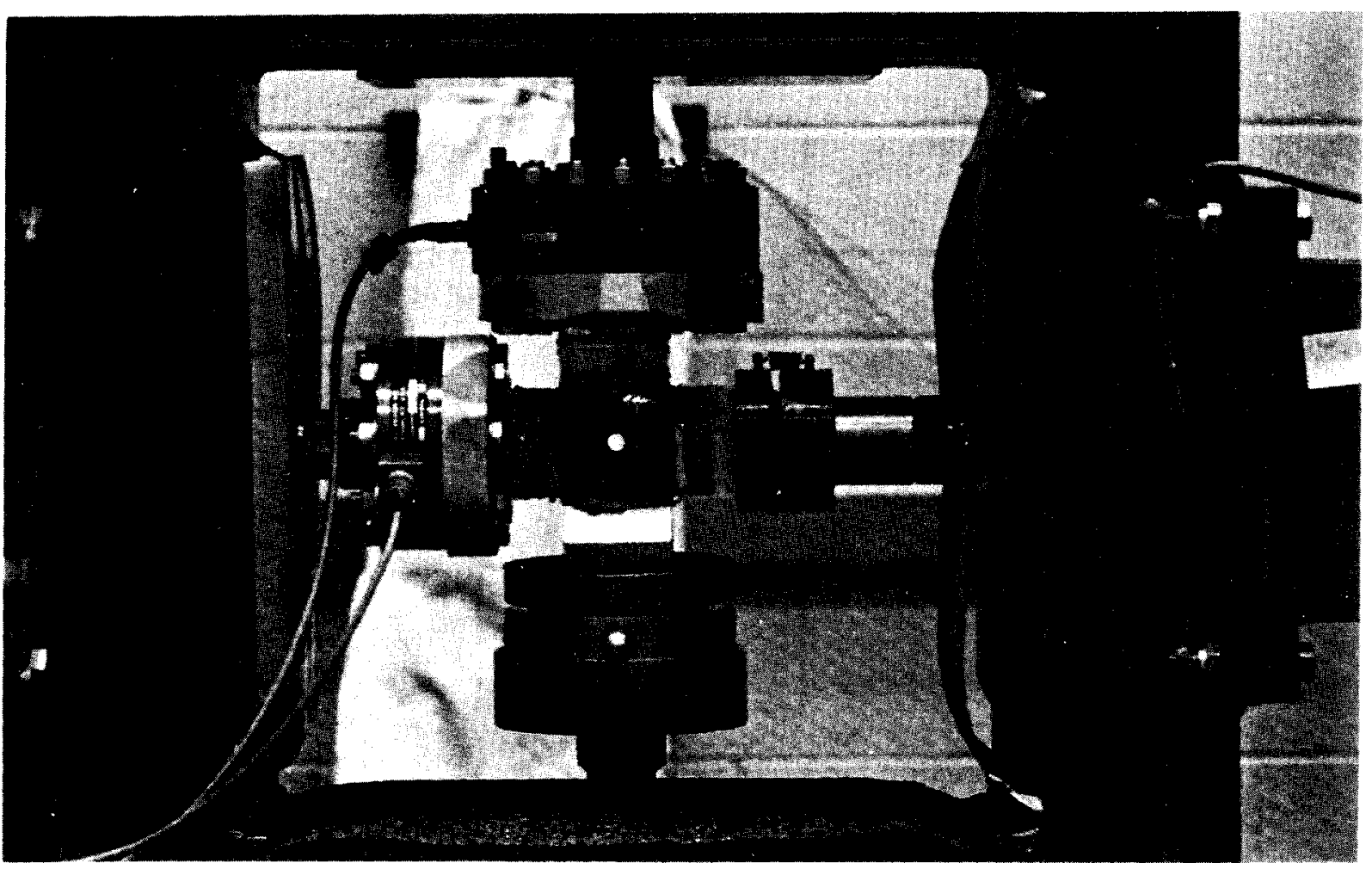

Fig. 2 Working Window in Frame 

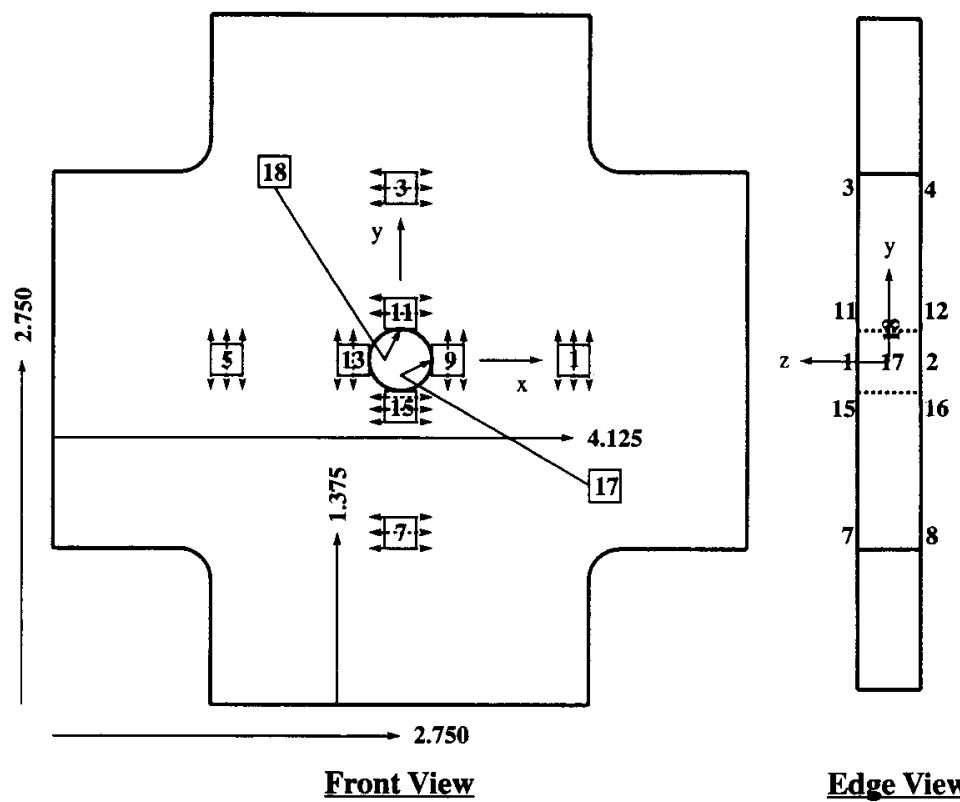

\section{$\underline{\text { Edge View }}$}

Note: $\mathrm{x}, \mathrm{y}$-axes lie along the lines of symmetry (-----) of the specimen panel.

Strain gages are paired (back to back) and placed along the lines of symmetry, as shown in the above figure.

Direction arrows $(\longrightarrow$ ) indicate the orientation of wiring in the strain gages.

All dimensions shown in the above figure are given in units of inches.

Dimension lengths are measured to the midpoint of the respective strain gages.

Fig. 3 Strain Gage Positioning on Specimens

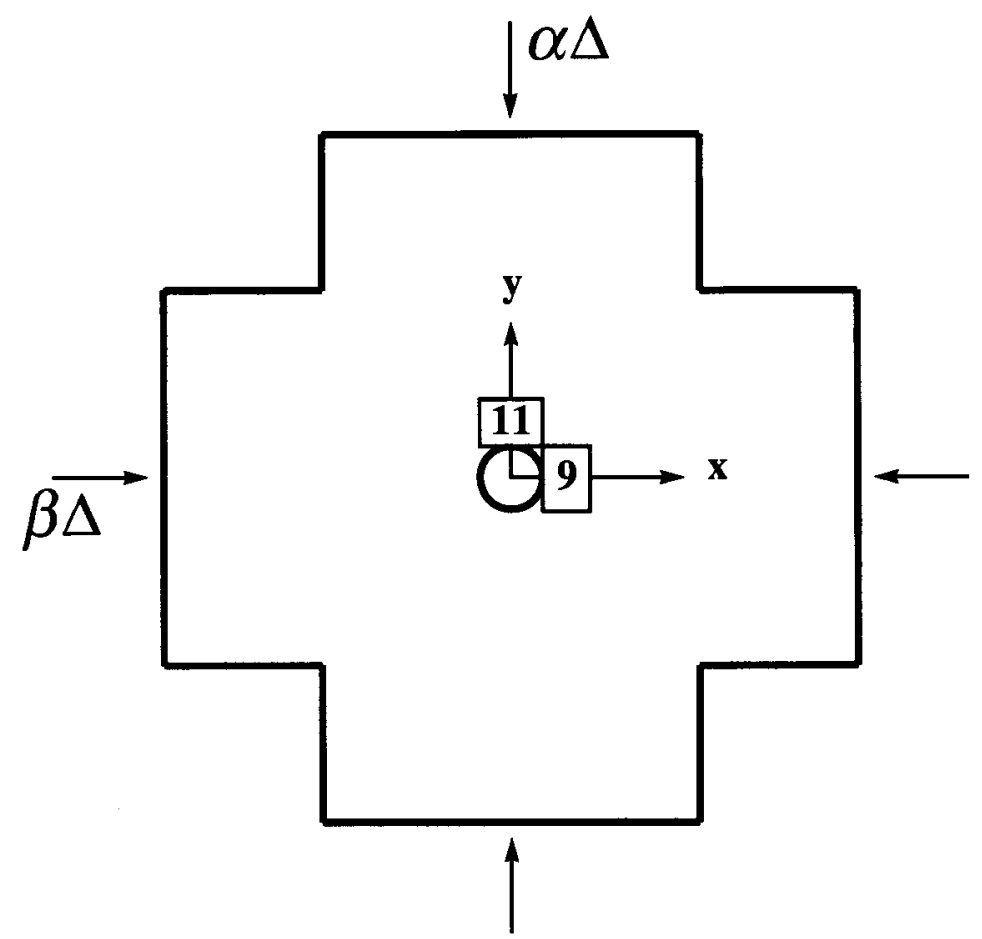

Fig. 4 Displacement Ratios 
Band of kinked fibers with fiber breaks at the band boundary
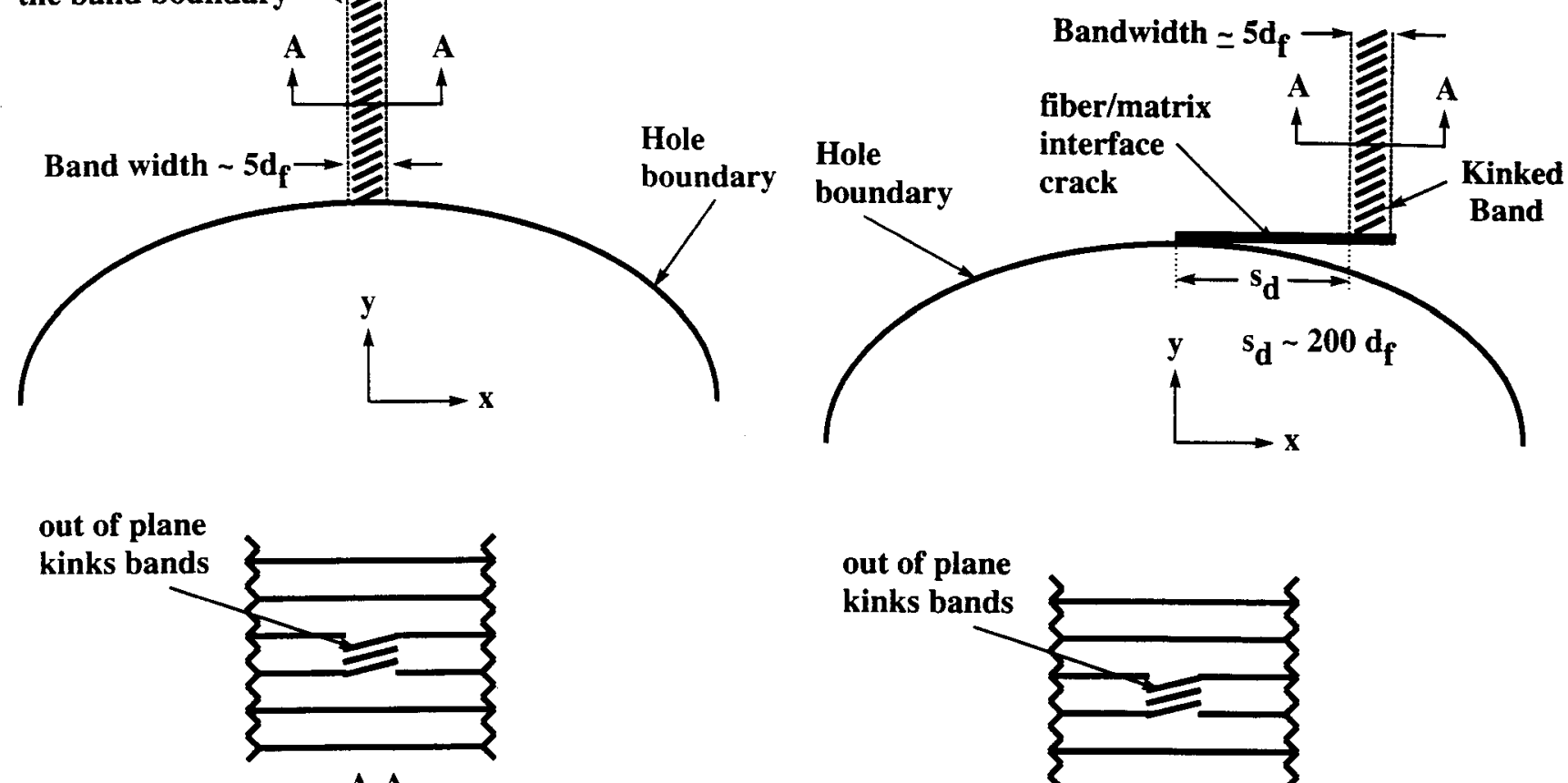

(a) 0-ply 1

A-A

\section{(a) 0-ply 1}

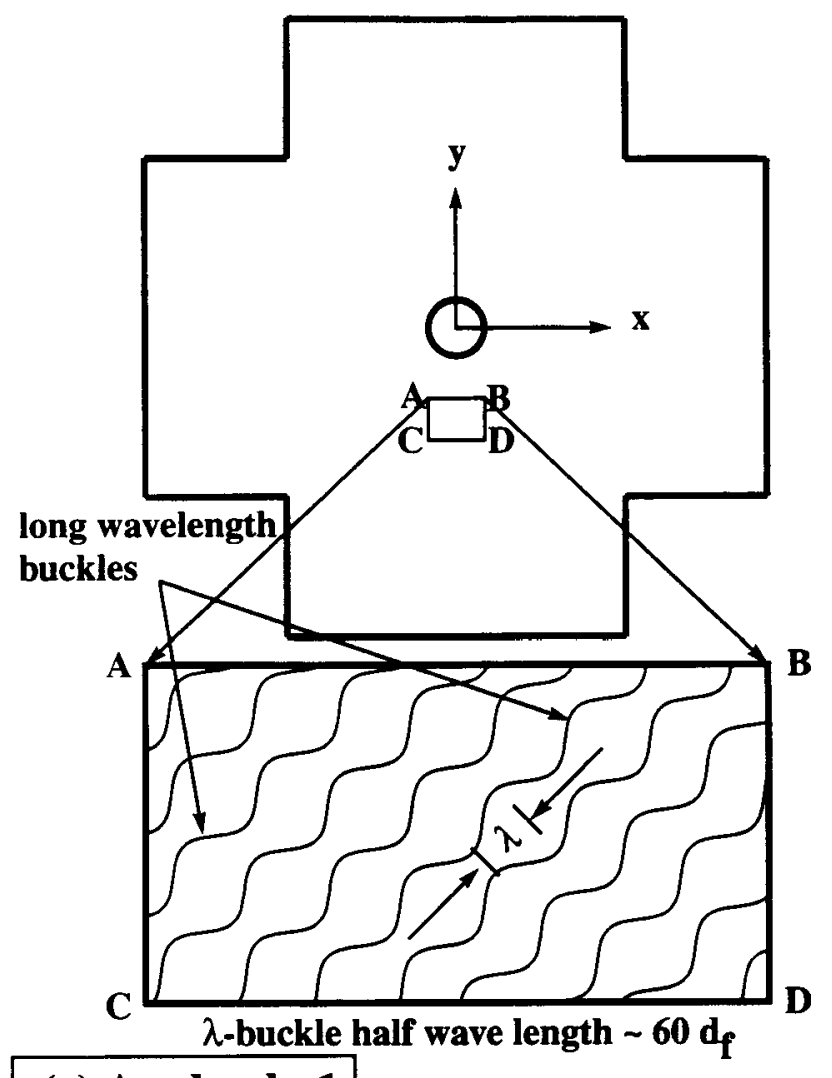

(c) Angle ply 1
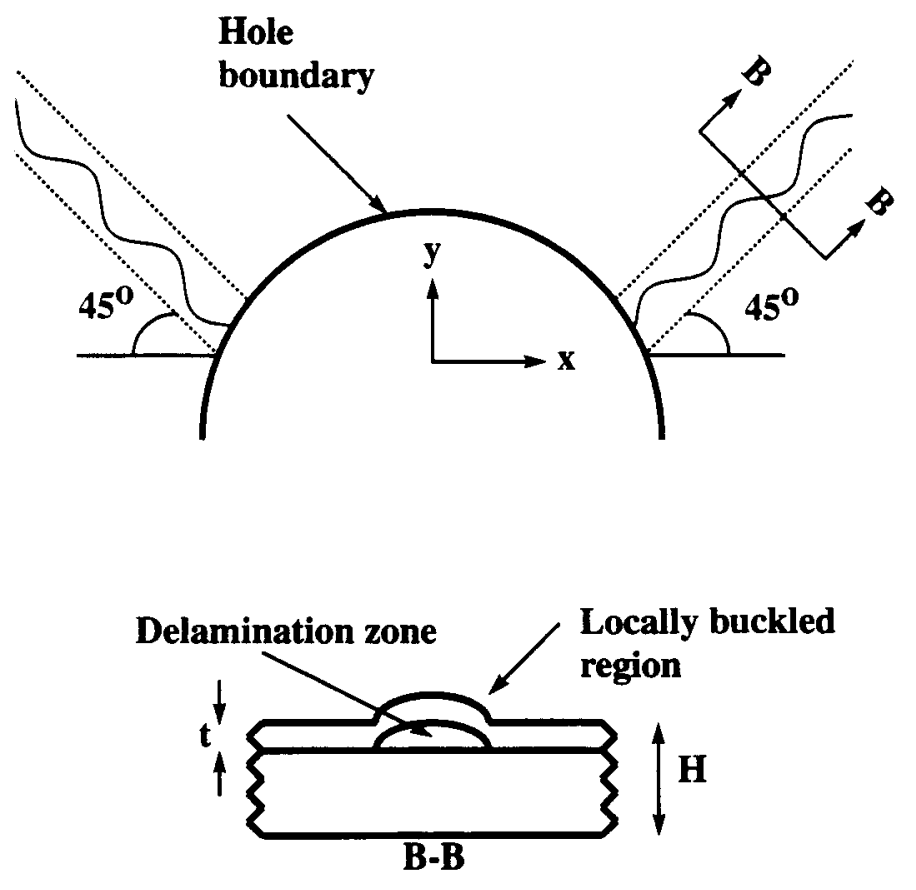

$\mathrm{t}$ (sublaminate thickness) $\sim \mathbf{0 . 2 5 H}$ $\mathrm{H}$ (laminate thickness) $\sim 0.285$ in.

(d) Angle ply 2 (Global)

Fig. 5 Failure Modes 